\title{
Production of succinic acid by engineered $E$. coli strains using soybean carbohydrates as feedstock under aerobic fermentation conditions
}

Chandresh Thakker ${ }^{1}$, George N. Bennett ${ }^{1, *}$, Ka-Yiu San ${ }^{2,3}$

${ }^{1}$ Department of Biochemistry and Cell Biology, Rice University, Houston, TX, USA

${ }^{2}$ Department of Bioengineering, Rice University, Houston, TX, USA

${ }^{3}$ Department of Chemical and Biomolecular Engineering, Rice University, Houston, TX, USA

*Corresponding author:

Dr. George N. Bennett

Department of Biochemistry and Cell Biology, MS-601

Rice University, 6100 Main Street

Houston, TX 77005-1892, USA

Tel.: (713) 348-4920

Fax: (713) 348-5154

E-mail: gbennett@,rice.edu 


\begin{abstract}
E. coli strains HL2765 and HL27659k harboring pRU600 and pKK313 were examined for succinate production under aerobic conditions using galactose, sucrose, raffinose, stachyose, and mixtures of these sugars extracted from soybean meal and soy solubles.

HL2765(pKK313)(pRU600) and HL27659k(pKK313)(pRU600) consumed $87 \mathrm{mM}$ and $98 \mathrm{mM}$ hexose of soybean meal extract and produced $83 \mathrm{mM}$ and $95 \mathrm{mM}$ succinate, respectively. While using soy solubles extract, HL2765(pKK313)(pRU600) and HL27659k(pKK313)(pRU600) consumed $160 \mathrm{mM}$ and $187 \mathrm{mM}$ hexose and produced $158 \mathrm{mM}$ and $183 \mathrm{mM}$ succinate, respectively. Succinate yield of HL2765(pKK313)(pRU600) was low as compared to that of HL27659k(pKK313)(pRU600) while using acid hydrolysate of soybean meal or soy solubles extracts. Maximum succinate production of $312 \mathrm{mM}$ with a molar yield of $0.82 \mathrm{~mol} / \mathrm{mol}$ hexose was obtained using soy solubles hydrolysate by HL27659k(pKK313)(pRU600). This study demonstrated the use of soluble carbohydrates of the renewable feedstock, soybean as an inexpensive carbon source to produce succinate by fermentation.
\end{abstract}

\title{
Keywords
}

Succinate, Escherichia coli, Aerobic fermentation, Soybean carbohydrates, Soy solubles 


\section{Introduction}

Succinic acid has been considered an important specialty chemical that can be produced by microorganisms. However, the placement of this molecule on the US Department of Energy (DOE) list of twelve platform chemicals from biomass (Werpy and Petersen, 2004) has generated widespread attention toward biobased succinate manufacturing (McKinlay et al., 2007). Various valuable molecules derived from succinic acid by known chemical processes are 1,4-butanediol, maleic anhydride, succinimide, 2-pyrrolidinone, and tetrahydrofuran; all of which have large markets and can be converted to a wide range of other valuable molecules for use in polymers (Xu and Guo, 2010), industrial solvents, and specialty chemicals, for example, biodegradable succinate esters (Budarin et al., 2007; Zeikus et al., 1999). Succinate is also used as a flavoring agent in food and as a counterion in many pharmaceutical formulations. Sodium dioctyl sulfosuccinate is used as a surfactant and wetting agent in textile and printing products and is a component of the Corexit dispersant used in the recent Gulf oil-spill cleanup operations (Thakker et al., 2012).

Major succinate producing organisms include Escherichia coli, Actinobacillus succinogenes, Anaerobiospirillum succiniciproducens, Mannheimia succiniciproducens, Corynebacterium glutamicum, Saccharomyces cerevisiae and Basfia succiniciproducens. Much work has been reported using these organisms to produce succinate with high yield and productivity and efforts are being made to commercialize succinate process by various groups. However, bio-based succinate still faces the challenge of becoming cost competitive against petrochemical-based processes (McKinlay et al., 2007). In order to develop a bio-based industrial production of succinic acid, it will be important to use low cost sugar rich feedstocks 
and develop a robust strain capable of catalyzing a wide range of sugar feedstocks to produce succinic acid in good yields so that the cheapest available raw material can be used.

Some of the above mentioned organisms were examined for their ability to use agricultural feedstocks for succinate production and increasingly the focus has been on the use of lignocellulosic-derived biomass as a feedstock (Borges and Pereira, 2011; Kim et al., 2004; Lee et al., 2003; Luo et al., 2010; Shanmugam and Ingram, 2008). A. succinogenes (Guettler et al., 1996; Li et al., 2011), M. succiniciproducens (Lee et al., 2008), A. succiniciproducens (Lee et al., 2008) can produce succinic acid from a broad range of carbon sources such as glucose, galactose, sucrose, maltose, lactose, xylose, and fructose. Most reported efforts to enhance production of succinate using A. succiniciproducens, A. succinogenes, and $M$. succiniciproducens have been performed under anaerobic conditions. These efforts have often been hampered by the limitations of NADH availability, poor cell growth, and slow production. In contrast, aerobic cell culture conditions have many advantages over anaerobic conditions that favor implementation on an industrial scale due to higher biomass generation, faster carbon throughput and product formation.

E. coli remains an attractive organism for testing new succinate technologies due to the extensive knowledge of its genome, proteome, availability of genetic tools, simple nutrient requirements, and facile cultivation. Lin et al. (2005a) strategically designed aerobic succinate producing recombinant $E$. coli strains in our laboratory. Based on pathway modeling and optimization, the maximum theoretical succinate yield that can be achieved using engineered E. coli under aerobic condition is $1.0 \mathrm{~mol}$ of succinate per mol of glucose consumed (Lin et al., 2005a and 2005b). Recently, Wang et al. (2011) demonstrated the production of succinate from 
sucrose (1.6-1.9 mol succinate/mol sucrose) under aerobic conditions using the engineered $E$. coli strains HL2765k and HL27659k harboring pHL413 and pUR400 plasmids.

In this study, we further explored the use of strains HL2765 and HL27659k harboring pKK313 (Lin et al., 2005a and 2005b) and pRU600 (Schmid and Schmitt, 1976; Aslanidis et al., 1989) for co-metabolizing various sugar substrates present in soybeans for succinate production. Soybeans, an important agriculture feedstock, are a major ingredient in non-ruminant animal diets. Soybeans contain approximately $37 \%$ crude protein and $20 \%$ oil. Defatted soybean meal has been widely used as a protein source in poultry, swine and other feed. Carbohydrate is the $2^{\text {nd }}$ most predominant component in soybean seeds representing approximately $35 \%$ of soybean meal dry matter (Giannoccaro et al., 2006). Cellulose, hemicellulose, pectin, and trace amounts of starch represent insoluble carbohydrates of soybeans (Liu 1997). Soluble carbohydrates consist of stachyose, raffinose, sucrose, glucose, fructose, and trace amounts of arabinose, rhamnose, fucose, ribose, xylose, and mannose (Eldridge et al., 1979). Consumption of the indigestible oligosaccharides, raffinose and stachyose results in flatulence and abdominal discomfort, so these are often removed during production of soy protein products.

Since the use of an inexpensive source of carbohydrates is an effective method among other possible alternatives to reduce the cost of fermentation process, we therefore aimed to demonstrate the use of the soluble carbohydrates including the nondigestible oligosaccharide fraction of soybean meal to produce succinate by aerobic fermentation using engineered $E$. coli strains. 


\section{Materials and methods}

\subsection{Oligosaccharides and soybean feedstock}

Raffinose and stachyose were obtained from B\&K Technology Group Co. Ltd., China. Soybean meal was obtained from Hieden Feed and Supply, Inc. (Houston, USA). Soy solubles obtained from Solae (St. Louis, MO) soy processing facility and stored in $50 \mathrm{~mL}$ aliquots at $-20^{\circ} \mathrm{C}$.

\subsection{Bacterial strains and plasmids}

Bacterial strains and plasmids used in this study are listed in Table 1. In our laboratory, succinate producing recombinant $E$. coli strains HL2765 $[\Delta s d h A B, \Delta($ ackA-pta $), \Delta$ poxB, $\Delta i c l R]$ and HL27659k $\left[\Delta s d h A B, \Delta(a c k A-p t a), \Delta p o x B, \Delta i c l R, \Delta p t s G:: \mathrm{Km}^{\mathrm{R}}\right]$ (Lin et al., 2005a) were constructed from GJT001 (Tolentino et al., 1992).

Plasmid pKK313, carrying the S8D mutation in the Sorghum vulgare pepc gene (Wang et al., 1992), was used to produce high levels of phosphoenol pyruvate carboxylase (PEPC) in the mutant $E$. coli strains (Lin et al., 2005a and 2005b). PEPC catalyzes the carboxylation of phosphoenolpyruvate (PEP) to oxaloacetate (OAA) and mediates the fixation of $\mathrm{CO}_{2}$. OAA is then sequentially reduced to malate and eventually converted to succinate. The pKK 313 plasmid confers ampicillin resistance and harbors altered pepc having a site-directed mutation that advantageously relieves malate feedback inhibition from the enzyme (Wang et al., 1992). Plasmids pRU600 and pUR400 were provided by Dr. Kurt Schmid (Universitat Osnabruck, Germany). The plasmid pRU600 bears chloramphenicol resistance and harbors $\operatorname{rafA}(\alpha-$ galactosidase), $r a f B$ (raffinose permease) and $r a f D$ (sucrose hydrolase) involved in the catabolism of raffinose (Schmid and Schmitt, 1976; Aslanidis et al., 1989). The plasmid pRU600 
allows the engineered E. coli strain HL2765 and HL27659k to metabolize raffinose and sucrose either individually in pure form or as a mixture under aerobic condition. The pUR400 plasmid $(70 \mathrm{~kb})$ has a tetracycline resistant marker and expresses $s c r K$ (fructokinase), $\operatorname{scr} Y$ (sucrosespecific porin), $s c r A$ (enzyme II ${ }^{\text {scr }}$ of the phosphotransferase system), $s c r B$ ( $\beta$-D-fructofuranoside fructohydrolase) and scrR (regulator) genes, which allows the metabolism of sucrose by converting sucrose 6-phosphate to $\beta$-D-fructose and $\alpha$-D-glucose 6-phosphate (Schmid et al., 1982 and 1988). The pUR400 plasmid was conjugated in E. coli strains as described by Wang et al. (2011). The plasmid pHL413 (Lin et al., 2004) overexpresses the pyc gene from Lactococcus lactis, which encodes the enzyme pyruvate carboxylase that converts pyruvate to oxaloacetate (OAA).

\subsection{Media, shake flask culture and cultivation conditions}

Luria-Bertani (LB) medium was used for culture cultivations. Appropriate concentrations of ampicillin (100-200 mg/L), kanamycin (30 mg/L) or chloramphenicol (25 mg/L) were added to the medium. Precultures were grown from glycerol stock in a $15 \mathrm{~mL}$ tubes containing $5 \mathrm{~mL}$ of LB medium with appropriate antibiotics. Overnight grown precultures were washed twice with LB and used as $1 \%(\mathrm{v} / \mathrm{v})$ inoculum.

A two-step culture technique, adapted from Sanchez et al. (2005), was used to examine succinate production. The first growth phase step was followed by the second step, the succinate production phase. Cells were aerobically grown at $37^{\circ} \mathrm{C}$ with shaking at $250 \mathrm{rpm}$ for $16-17 \mathrm{~h}$ in 2 L flasks containing $400 \mathrm{~mL}$ of LB medium with appropriate antibiotics. Cells were harvested by centrifugation and the supernatant was discarded. The cells were then resuspended in $10 \mathrm{~mL}$ of soybean meal extract, soy solubles extract or its hydrolysate to a final concentration of $20 \mathrm{OD}_{600}$. 
While using raffinose, stachyose, sucrose or galactose as the sole carbon source to examine succinate production, the cells were resuspended in $10 \mathrm{~mL}$ LB containing an appropriate concentration of the sugar. After resuspension, the cultures were transferred aseptically to 250 $\mathrm{mL}$ previously autoclaved flasks containing $0.3 \mathrm{~g}$ of $\mathrm{MgCO}_{3}$. Sterile foam stoppers were used as cap for $2 \mathrm{~L}$ and $250 \mathrm{~mL}$ flasks. All cultures were cultivated at $37^{\circ} \mathrm{C}$ and $250 \mathrm{rpm}$. Samples were collected at 24-48 $\mathrm{h}$ for HPLC analysis.

\subsection{Extraction of soluble carbohydrates from soybean meal and hydrolysis of oligosaccharides}

Twenty grams of soybean meal was added to $100 \mathrm{~mL}$ water and stirred at room temperature for $15 \mathrm{~min}$. The content was centrifuged at $10,000 \times \mathrm{g}$ for $10 \mathrm{~min}$ to remove wet soybean meal and the supernatant, herein referred as soybean meal extract, containing soluble carbohydrates was recovered. To prepare soybean meal hydrolysate, $0.3 \%(\mathrm{v} / \mathrm{v})$ concentrated $\mathrm{H}_{2} \mathrm{SO}_{4}$ was added to the soybean meal extract and mixed by stirring for 1-2 min followed by incubation at $100^{\circ} \mathrm{C}$ for $1 \mathrm{~h}$. After cooling to room temperature, the content was centrifuged at $10,000 \times \mathrm{g}$ for $15 \mathrm{~min}$ to remove debris. The supernatant, referred to as soybean meal hydrolysate, was recovered and neutralized to $\mathrm{pH} 7.0$ with $8 \mathrm{M} \mathrm{NaOH}$.

Twenty grams of a thick slurry of soy solubles was added to water with a final volume of $100 \mathrm{~mL}$ and stirred at room temperature for $15 \mathrm{~min}$. The content was centrifuged at $10,000 \times g$ for $10 \mathrm{~min}$ and the supernatant, referred as soy solubles extract, containing soluble carbohydrates was recovered. To prepare soy solubles hydrolysate, concentrated $\mathrm{H}_{2} \mathrm{SO}_{4}(1 \% \mathrm{v} / \mathrm{v})$ was added to soy solubles extract and mixed by stirring for $1-2$ min followed by incubation at $100^{\circ} \mathrm{C}$ for $1 \mathrm{~h}$. After cooling to room temperature, the content was centrifuged at $10,000 \times g$ for 15 min to remove debris. The supernatant, referred as soy solubles hydrolysate, was recovered and 
neutralized to $\mathrm{pH} 7.0$ with $8 \mathrm{M} \mathrm{NaOH}$. Soybean meal extract, soybean meal hydrolysate, soy solubles extract and soy solubles hydrolysate solutions were filtered through a $0.2 \mu \mathrm{m}$ filter assembly prior to their use in fermentation experiments.

\subsection{Analytical techniques}

Cell density was measured at $600 \mathrm{~nm}$ using a UV-Vis spectrophotometer (DU800, Beckman Coulter, USA). Samples were diluted appropriately to the linear range with $0.9 \%(\mathrm{w} / \mathrm{v})$ $\mathrm{NaCl}$. For analyzing the extracellular metabolites, $1 \mathrm{~mL}$ of fermented broth was centrifuged for 1 min at $10,000 \times g$ in a microcentrifuge and the supernatant was then filtered through a $0.2 \mu \mathrm{m}$ syringe filter for HPLC analysis. The fermentation products and residual sugars were quantified using a HPLC system (Shimadzu, Japan), equipped with a cation-exchange column (Aminex HPX-87H; Bio-Rad, USA), a UV detector (Shimadzu SPD-10A), and a differential refractive index detector (Waters, USA). A mobile phase of $2.5 \mathrm{mM} \mathrm{H}_{2} \mathrm{SO}_{4}$ solution at a $0.4 \mathrm{~mL} / \mathrm{min}$ flow rate was used and the column operated at $28^{\circ} \mathrm{C}$. Succinate, formate, acetate, fumarate, stachyose, raffinose, sucrose, glucose, galactose and fructose were measured by the RI detector and pyruvate was measured by the UV detector at $210 \mathrm{~nm}$. Galactose and fructose were found to have similar retention times and therefore, quantified as residual galactose and or fructose.

While using galactose, sucrose and raffinose individually in pure form, the succinate yield was expressed as mol of succinate produced per mol of sugar consumed. In case of soluble sugars mixture containing glucose, galactose, fructose, sucrose, raffinose and stachyose, the succinate yield was expressed as mol of succinate produced per mol of hexose consumed. Each of these sugars was individually quantified by HPLC and the amount converted to monomeric hexose units to calculate total hexose consumed during fermentation. 


\section{Results and discussion}

\subsection{Fermentation of galactose, sucrose, raffinose and stachyose}

In this study, we first examined HL2765 and HL27659k strains harboring pKK313 and pRU600 plasmids to see how well both strains are able to produce succinate using various concentrations of stachyose, raffinose, sucrose and galactose individually in pure form before testing them on soy based substrates that contain a mixture of these sugars.

Galactose metabolism and succinate production by HL2765(pKK313)(pRU600) and HL27659k(pKK313)(pRU600) were examined using different concentrations of initial galactose in the range of 10 to $30 \mathrm{~g} / \mathrm{L}$ (Fig. 1A and B). Strain HL2765(pKK313)(pRU600) consumed 52, 111.21 and $160.30 \mathrm{mM}$ galactose in $24 \mathrm{~h}$ and produced $51.74,82.81$ and $114.55 \mathrm{mM}$ succinate with succinate yields of $0.99,0.74$ and $0.71 \mathrm{~mol} / \mathrm{mol}$ galactose while using 10,20 and $30 \mathrm{~g} / \mathrm{L}$ galactose, respectively. Whereas, strain HL27659k(pKK313)(pRU600) consumed 55.60, 111.60 and $163.15 \mathrm{mM}$ galactose in $24 \mathrm{~h}$ and produced 53.16, 92.30 and $120.63 \mathrm{mM}$ succinate with succinate yields of $0.95,0.82$ and $0.74 \mathrm{~mol} / \mathrm{mol}$ galactose while using 10,20 and $30 \mathrm{~g} / \mathrm{L}$ galactose, respectively. Trace amount of byproducts such as formate, acetate and fumarate were also observed for both strains, specifically, a high concentration of acetate $(17-20 \mathrm{mM})$ was seen while using $30 \mathrm{~g} / \mathrm{L}$ galactose (Fig. 1A and B). It was observed that with increasing galactose concentration, succinate production increased, however, succinate yield decreased in both strains. Both strains were capable to efficiently utilize almost all of the initial available galactose within $24 \mathrm{~h}$.

Metabolism of disaccharide sucrose in the range of 10 to $30 \mathrm{~g} / \mathrm{L}$ and succinate production was examined using HL2765(pKK313)(pRU600) and HL27659k(pKK313)(pRU600) (Fig. 2A 
and B). Both strains were capable to efficiently metabolize sucrose to succinate in presence of plasmid pRU600 harboring rafD (sucrose hydrolase). With increasing sucrose concentration up to $30 \mathrm{~g} / \mathrm{L}$, succinate production by these two strains also increased. The strain HL2765(pKK313)(pRU600) consumed 9.25, 48.44, $79.26 \mathrm{mM}$ sucrose in $24 \mathrm{~h}$ and produced $17.70,88.52$ and $129 \mathrm{mM}$ succinate with succinate yields of $1.91,1.82$ and $1.62 \mathrm{~mol} / \mathrm{mol}$ sucrose while using 10, 20 and $30 \mathrm{~g} / \mathrm{L}$ sucrose, respectively. In comparison, strain HL27659k(pKK313)(pRU600) consumed 16.20, 51 and $80.50 \mathrm{mM}$ sucrose in $24 \mathrm{~h}$ and produced $29,85.80$ and $134.85 \mathrm{mM}$ succinate with succinate yields of $1.78,1.68$ and $1.67 \mathrm{~mol} / \mathrm{mol}$ sucrose while using 10, 20 and $30 \mathrm{~g} / \mathrm{L}$ sucrose, respectively. Trace amounts $(0.7-1 \mathrm{mM})$ of acetate were also observed (Fig. 2A and B). Previously, Wang et al. (2011) reported the production of succinate from sucrose using HL2765k(pHL413)(pUR400) and HL27659k(pHL413)(pUR400). HL2765k(pHL413)(pUR400) was reported to produce $22 \mathrm{mM}$ succinate in $46 \mathrm{~h}$ with succinate yield of $1.60 \mathrm{~mol} / \mathrm{mol}$ sucrose, whereas, HL27659k(pHL413)(pUR400) produced $24 \mathrm{mM}$ succinate with succinate yield of $1.84 \mathrm{~mol} / \mathrm{mol}$ sucrose. Results of these two studies suggest that strains HL2765 and HL27659k harboring plasmids pHL413 and pUR400 or pKK313 and pRU600 are capable to efficiently metabolize sucrose to succinate.

Raffinose fermentation by HL2765(pKK313)(pRU600) and HL27659k(pKK313)(pRU600) to succinate was examined using 5 and $10 \mathrm{~g} / \mathrm{L}$ raffinose (Fig. 3A and B). The strain HL2765(pKK313)(pRU600) produced $29 \mathrm{mM}$ and $47.4 \mathrm{mM}$ succinate from $9.87 \mathrm{mM}$ and $19 \mathrm{mM}$ raffinose with succinate yields of 2.93 and $2.49 \mathrm{~mol} / \mathrm{mol}$ raffinose, respectively (Fig. 3A). Whereas, HL27659k(pKK313)(pRU600) produced $29 \mathrm{mM}$ and 53.88 $\mathrm{mM}$ succinate from $9.71 \mathrm{mM}$ and $19.72 \mathrm{mM}$ raffinose with succinate yields of 2.98 and 2.73 $\mathrm{mol} / \mathrm{mol}$ raffinose, respectively (Fig. 3B). Both strains were capable to efficiently utilize almost 
all of the initial available raffinose within $24 \mathrm{~h}$. The efficient catabolism of raffinose by HL2765 and HL27659k was due to the presence of the pRU600 plasmid harboring rafA ( $\alpha$-galactosidase), $r a f B$ (raffinose permease) and $r a f D$ (sucrose hydrolase) genes (Aslanidis et al., 1989). Cornelis et al. (1978) reported that raffinose can be transported by the lactose permease, and isolated lacI constitutive mutants of $E$. coli K-12 capable of raffinose uptake and metabolism. Moniruzzaman et al. (1997) isolated raffinose positive mutants of KO11, a derivative of $E$. coli B, by culture enrichment in presence of raffinose and the adapted strain may contain an analogous mutation.

Strains HL2765(pKK313)(pRU600) and HL27659k(pKK313)(pRU600) were examined for stachyose catabolism using 5 and $10 \mathrm{~g} / \mathrm{L}$ stachyose. However, both strains showed poor utilization (1-3 mM in $24 \mathrm{~h}$ ) of stachyose (data not shown). This could be due to the lack of specific glycoporin for stachyose transport in the host strains used in this study. In E. coli the uptake of tetrasaccharides, such as stachyose, and longer oligosaccharides, like maltodextrins, requires glycoporins (Ulmke et al., 1997). Results of the above experiments and previous studies (Lin et al., 2005a; Wang et al., 2011) showed the potential of engineered E. coli strains HL2765 and HL27659k harboring either pHL413 and pUR400 or pKK313 and pRU600 to efficiently metabolize glucose, galactose, fructose, sucrose and raffinose under aerobic conditions to produce succinate.

\subsection{Production of succinate using soybean meal extract and its hydrolysate}

HPLC analysis of soybean meal extract showed the presence of $19 \mathrm{mM}$ stachyose, $2 \mathrm{mM}$ raffinose, $48 \mathrm{mM}$ sucrose, $5 \mathrm{mM}$ galactose and or fructose, and $10 \mathrm{mM}$ glucose which correspond to a total hexose concentration of about $193 \mathrm{mM}$. In comparison, soybean meal hydrolysate contains $1 \mathrm{mM}$ stachyose, $13 \mathrm{mM}$ raffinose, $25 \mathrm{mM}$ sucrose, $55 \mathrm{mM}$ galactose and 
or fructose, and $42 \mathrm{mM}$ glucose, which corresponds to a total hexose concentration of about 190 $\mathrm{mM}$.

Succinate production using soybean meal extract by strains HL2765(pKK313)(pRU600) and HL27659k(pKK313)(pRU600) at $24 \mathrm{~h}$ is shown in Fig. 4A. HL2765(pKK313)(pRU600) consumed $1.62 \mathrm{mM}$ stachyose, $2 \mathrm{mM}$ raffinose, $33.72 \mathrm{mM}$ sucrose, $2.62 \mathrm{mM}$ galactose and or fructose and $4.28 \mathrm{mM}$ glucose which corresponds to about $87 \mathrm{mM}$ hexose out of $193 \mathrm{mM}$ total hexose available in soybean meal extract and produced $83 \mathrm{mM}$ succinate in $24 \mathrm{~h}$ with a succinate yield of $0.95 \mathrm{~mol} / \mathrm{mol}$ hexose. Whereas, HL27659k(pKK313)(pRU600) consumed $1.5 \mathrm{mM}$ stachyose, $2 \mathrm{mM}$ raffinose, $37.22 \mathrm{mM}$ sucrose, $2.67 \mathrm{mM}$ galactose and or fructose and $8.90 \mathrm{mM}$ glucose which corresponds to about $98 \mathrm{mM}$ hexose out of $193 \mathrm{mM}$ total hexose available in soybean meal extract and produced $95 \mathrm{mM}$ succinate with succinate yield of $0.97 \mathrm{~mol} / \mathrm{mol}$ hexose. Minor amounts (about $1 \mathrm{mM}$ ) of byproducts acetate and pyruvate were also observed for both strains (Fig. 4A).

We also examined the capability of strains HL2765(pKK313)(pRU600) and HL27659k(pKK313)(pRU600) to produce succinate using soybean meal hydrolysate containing $190 \mathrm{mM}$ hexose sugars (Fig. 4B). HL2765(pKK313)(pRU600) consumed $12 \mathrm{mM}$ raffinose, 14 $\mathrm{mM}$ sucrose, $50 \mathrm{mM}$ galactose and or fructose and $25 \mathrm{mM}$ glucose which corresponds to about $139 \mathrm{mM}$ hexose to produce $87 \mathrm{mM}$ succinate in $24 \mathrm{~h}$. The molar succinate yield achieved for this strain was $0.62 \mathrm{~mol} / \mathrm{mol}$ hexose. The strain produced about $3 \mathrm{mM}$ formate and $5 \mathrm{mM}$ acetate as byproducts (Fig. 4B). As compared to HL2765(pKK313)(pRU600), the strain HL27659k(pKK313)(pRU600) consumed $13 \mathrm{mM}$ raffinose, $14.5 \mathrm{mM}$ sucrose, $52 \mathrm{mM}$ galactose and or fructose and $23 \mathrm{mM}$ glucose which corresponds to about $143 \mathrm{mM}$ hexose to produce 120 $\mathrm{mM}$ succinate, $2 \mathrm{mM}$ formate and $0.4 \mathrm{mM}$ acetate in $24 \mathrm{~h}$ (Fig. 4B). The molar succinate yield 
for HL27659k(pKK313)(pRU600) was $0.83 \mathrm{~mol} / \mathrm{mol}$ hexose, which was 1.3 fold higher than HL2765(pKK313)(pRU600). Both strains consumed more hexose sugars present in soybean meal hydrolysate as compared to soybean meal extract. However, molar succinate yield obtained using soybean meal hydrolysate was lower as compared to soybean meal extract. It is not clear why the molar succinate yield dropped while using soybean meal hydrolysate.

\subsection{Production of succinate using soy solubles extract and its hydrolysate}

We obtained soy solubles slurry, a byproduct rich in soluble sugars, from a soy processing industry. Soluble sugars were recovered from soy solubles as explained in materials and methods and used to demonstrate succinate production using HL2765(pKK313)(pRU600) and HL27659k(pKK313)(pRU600). HPLC analysis of soy solubles extract showed the presence of $45 \mathrm{mM}$ stachyose, $13 \mathrm{mM}$ raffinose, $90 \mathrm{mM}$ sucrose, $12 \mathrm{mM}$ galactose and or fructose, and 30 $\mathrm{mM}$ glucose which corresponds to a total hexose concentration of $441 \mathrm{mM}$. Whereas, soy solubles hydrolysate contains $37 \mathrm{mM}$ raffinose, $31 \mathrm{mM}$ sucrose, $147 \mathrm{mM}$ galactose and or fructose, and $111 \mathrm{mM}$ glucose, which corresponds to a total hexose concentration of about 431 $\mathrm{mM}$.

Succinate production by strains HL2765(pKK313)(pRU600) and HL27659k(pKK313)(pRU600) using soy solubles extract is shown in Fig. 5. HL2765(pKK313)(pRU600) consumed $13 \mathrm{mM}$ raffinose, $53.82 \mathrm{mM}$ sucrose, $5.11 \mathrm{mM}$ galactose and or fructose and $8.22 \mathrm{mM}$ glucose which corresponds to $160 \mathrm{mM}$ hexose out of $441 \mathrm{mM}$ total hexose available in soy solubles extract and produced $158 \mathrm{mM}$ succinate, $18 \mathrm{mM}$ formate and 9 $\mathrm{mM}$ acetate in $24 \mathrm{~h}$. The molar succinate yield was $0.98 \mathrm{~mol} / \mathrm{mol}$ hexose. Whereas, HL27659k(pKK313)(pRU600) consumed $2 \mathrm{mM}$ stachyose, $13 \mathrm{mM}$ raffinose, $60.43 \mathrm{mM}$ sucrose, 
$4.72 \mathrm{mM}$ galactose and or fructose and $14.42 \mathrm{mM}$ glucose which corresponds to $187 \mathrm{mM}$ hexose out of $441 \mathrm{mM}$ total hexose available in soy solubles extract and produced $183 \mathrm{mM}$ succinate, 19 $\mathrm{mM}$ formate and $0.56 \mathrm{mM}$ acetate in $24 \mathrm{~h}$. The molar succinate yield was $0.97 \mathrm{~mol} / \mathrm{mol}$ hexose (Fig. 5). Thus, both strains were capable of producing succinate with close to maximum theoretical succinate yield using extracted soluble sugars of soy solubles.

Soy solubles extract was treated with concentrated $\mathrm{H}_{2} \mathrm{SO}_{4}$ to hydrolyze stachyose to raffinose, sucrose and hexose sugars for metabolisms by engineered E. coli strains HL2765(pKK313)(pRU600) and HL27659k(pKK313)(pRU600). Succinate production and hexose consumption by these two strains using soy solubles hydrolysate is shown in Fig. 6A and B. HL2765(pKK313)(pRU600) consumed $22.61 \mathrm{mM}$ raffinose, $5.68 \mathrm{mM}$ sucrose, $139.62 \mathrm{mM}$ galactose and or fructose and $75.19 \mathrm{mM}$ glucose which corresponds to $294 \mathrm{mM}$ hexose out of total $431 \mathrm{mM}$ hexose present in soy solubles hydrolysate and produced $204 \mathrm{mM}$ succinate with succinate yield of $0.69 \mathrm{~mol} / \mathrm{mol}$ hexose in $24 \mathrm{~h}$. Additionally, the strain produced $20 \mathrm{~mm}$ formate, $46 \mathrm{mM}$ acetate and $39 \mathrm{mM}$ pyruvate. Whereas in $48 \mathrm{~h}$, the strain consumed $30 \mathrm{mM}$ raffinose, $21.55 \mathrm{mM}$ sucrose, $140 \mathrm{mM}$ galactose and or fructose and $80 \mathrm{mM}$ glucose which corresponds to $353 \mathrm{mM}$ hexose sugars and produced $246 \mathrm{mM}$ succinate with a succinate yield of $0.7 \mathrm{~mol} / \mathrm{mol}$ hexose. Byproducts were $17 \mathrm{mM}$ formate, $110 \mathrm{mM}$ acetate and $24 \mathrm{mM}$ pyruvate (Fig. 6A). As compared to HL2765(pKK313)(pRU600), the strain HL27659k(pKK313)(pRU600) consumed $32.52 \mathrm{mM}$ raffinose, $24.98 \mathrm{mM}$ sucrose, $79.68 \mathrm{mM}$ galactose and or fructose and $78.80 \mathrm{mM}$ glucose which corresponds to $306 \mathrm{mM}$ hexose out of total $431 \mathrm{mM}$ hexose present in soy solubles hydrolysate and produced $250 \mathrm{mM}$ succinate, 26 $\mathrm{mM}$ formate and $30 \mathrm{mM}$ acetate in $24 \mathrm{~h}$. Whereas in $48 \mathrm{~h}$, the strain consumed $37 \mathrm{mM}$ raffinose, $26.69 \mathrm{mM}$ sucrose, $135.84 \mathrm{mM}$ galactose and or fructose and $80 \mathrm{mM}$ glucose which corresponds 
to $380 \mathrm{mM}$ hexose and produced $312 \mathrm{mM}$ succinate, $27 \mathrm{mM}$ formate and $50 \mathrm{mM}$ acetate (Fig. 6B). The molar succinate yields for HL27659k(pKK313)(pRU600) at $24 \mathrm{~h}$ and $48 \mathrm{~h}$ was 0.81 and $0.82 \mathrm{~mol} / \mathrm{mol}$ hexose, respectively. These results showed that both strains were capable of efficiently consuming hexose up to $48 \mathrm{~h}$ of fermentation and produced high succinate without decreasing molar succinate yields. It was interesting to observe that HL2765(pKK313)(pRU600) consumed less raffinose and sucrose but more galactose and or fructose in $24 \mathrm{~h}$ as compared to HL27659k(pKK313)(pRU600).

Despite the fact that the acetate producing pathways were knocked out, we noticed that both strains accumulated acetate, specifically increased acetate accumulation in $48 \mathrm{~h}$. This could be due to a number of minor acetate producing pathways such as acetylornithine deacetylase and citrate lyase (Sanchez et al., 2005). It was interesting to observe accumulation of pyruvate in culture broth of the strain HL2765(pKK313)(pRU600) (Fig.6A). However, the strain HL27659k(pKK313)(pRU600) did not show accumulation of pyruvate. This could be due to the PtsG system which is active in the strain HL2765(pKK313)(pRU600). Pyruvate accumulation in the strain HL2765(pKK313)(pRU600) can be reduced by increasing OAA through coexpression of PEPC and L. lactis PYC (Lin et al., 2005c) that could result in higher succinate production.

Wang et al. (2011) reported efficient succinate production from sucrose under aerobic conditions using E. coli strains HL2765k and HL27659k harboring pUR400 and pHL413. As pUR400 expresses sucrose catabolizing genes, we thought using this plasmid along with pRU600 might help in efficient uptake and metabolism of sucrose by engineered E. coli strains. Therefore, we studied the effect of using pUR400 in combination of pRU600 and pKK313. Succinate production was examined using soy solubles hydrolysate using HL27659k(pKK313)(pRU600) and HL27659k(pKK313)(pRU600)(pUR400) strains. However, 
the molar succinate yield dropped to $0.6 \mathrm{~mol} / \mathrm{mol}$ hexose for the strain

HL27659k(pKK313)(pRU600)(pUR400) (data not shown) as compared to $0.81 \mathrm{~mol} / \mathrm{mol}$ hexose obtained by HL27659k(pKK313)(pRU600). HL27659k(pKK313)(pRU600)(pUR400) did not show significant improvement in sucrose uptake. Similarly, we examined the succinate production from soy solubles hydrolysate using HL27659k(pKK313)(pRU600) and HL27659(pHL413)(pRU600) to evaluate the effect of PYC overexpression as compared to PEPC overexpression. The strain HL27659k(pHL413)(pRU600) consumed only about $50 \mathrm{mM}$ hexose and produced $40 \mathrm{mM}$ succinate in $24 \mathrm{~h}$ (data not shown).

Lignocellulosic biomass rich in cellulose, hemicellulose and lignin, has attracted much attention as a source of reducing sugars to produce biofuels by fermentation. However, in order to use this material in bioprocesses, various chemical, mechanical, thermo-chemical and biochemical pretreatments have been investigated, including acid hydrolysis, alkali hydrolysis, steam explosion, or ammonia fiber explosion (Yoo et al., 2011). Thermo-mechanical extrusion pretreatment for the conversion of cellulosic sugars present in soybean hulls to fermentable sugars and their use to produce ethanol by Saccharomyces cerevisiae have been reported (Yoo et al., 2011 and 2012). Fermentation inhibitors, such as furfural, 5-(hydroxymethyl)-2-furaldehyde (HMF), and acetic acid, were found in the extrusion pretreated soybean hulls and hydrolysate. However, their concentrations were below the known thresholds for inhibition (Yoo et al., 2012). As compared to the harsh lignocellulosic biomass pretreatments, in the present study we used diluted sulphuric acid to hydrolyze soluble oligosaccharides, specifically stachyose, into fermentable sugars. However, it remains to be examined if there are any fermentation inhibitors present in soybean meal extract hydrolysate or soy solubles extract hydrolysate and at what 
concentrations. In such circumstances, further pretreatment methods could be examined to minimize inhibitory effects and thereby to improve sugar metabolism and succinate production.

This study successfully demonstrated the use of soybean derived soluble sugar feedstock for the aerobic production of succinate. Further improvement in succinate yield and titer could be achieved by performing batch or fed-batch fermentation under controlled conditions using a bioreactor. To further reduce the process cost, attempts are being made to replace complex and expensive Luria broth medium with soybean meal extract or soy solubles based medium for culture growth and succinate production. In addition, there are other oilseeds that contain valuable carbohydrates. In this context, we have examined cottonseed meal extract carbohydrates in a similar process and obtained succinate with these strains. Additionally, pepc and raffinose operon genes could be integrated into the HL27659k strain for more stable gene expression and thereby eliminating the need for addition of antibiotics during fermentation process.

\section{Conclusions}

In the development of a succinic acid production process, the cost of raw material is an important factor. In this study, an efficient succinic acid production process using metabolically engineered E. coli strains HL2765 and HL27659k harboring pRU600 and pKK313 plasmids was demonstrated using soluble sugars extracted from soybean meal and soy solubles. Both strains showed capability to simultaneously metabolize multiple sugars and osmotolerance to high initial sugar concentration during the aerobic succinate fermentation process with close to theoretical molar succinic acid yield. HL27659k(pRU600)(pKK313) could be a potential strain for economic aerobic succinate production from renewable substrates such as soybeans. 


\section{Acknowledgements}

This work was supported by the United Soybean Board (USB). We also acknowledge support from NSF CBET-1033552. We thank Dr. Kurt Schmid (Universitat Osnabruck,

Germany) for providing E. coli strains harboring pUR400 and pRU600 plasmid, and thank Craig

Russett, Director, Agribusiness at Solae LLC, Fort Wayne, Indiana for the soy solubles samples.

\section{References}

Aslanidis, C., Schmid, K., Schmitt, R., 1989. Nucleotide sequences and operon structure of plasmid-borne genes mediating uptake and utilization of raffinose in Escherichia coli. J. Bacteriol. 171(12), 6753-6763.

Borges, E.R., Pereira, N., Jr., 2011. Succinic acid production from sugarcane bagasse hemicellulose hydrolysate by Actinobacillus succinogenes. J. Ind. Microbiol. Biotechnol. 38(8), 1001-1011.

Budarin, V., Luque, R., Macquarrie, D.J., Clark, J.H., 2007. Towards a bio-based industry: benign catalytic esterifications of succinic acid in the presence of water. Chemistry. 13(24), 6914-6919.

Cornelis, G., Luke, R. K. J., Richmond, M. H., 1978. Fermentation of raffinose by lactosefermenting strains of Yersinia enterocolitica and by sucrose-fermenting strains of Escherichia coli. J. Clin. Microbiol. 7, 180-183.

Eldridge, A.C., Black, L.T., Wolf, J.W., 1979. Carbohydrate composition of soybean flours, protein concentrates, and isolates. J. Agric. Food Chem. 27, 799-802.

Giannoccaro, E., Wang, Y.J., Chen, P., 2006. Effects of solvent, temperature, time, solvent-tosample ratio, sample size, and defatting on the extraction of soluble sugars in soybean. J. 
Food Sci. 71, C59-C64.

Guettler, M.V., Jain, M.K., Rumler, D. 1996. Method for making succinic acid, bacterial variants for use in the process, and methods for obtaining variants. US Patent 5,573,931.

Kim, D.Y., Yim, S.C., Lee, P.C., Lee, W.G., Lee, S.Y., Chang, H.N., 2004. Batch and continuous fermentation of succinic acid from wood hydrolysate by Mannheimia succiniciproducens MBEL55E. Enzyme Microb. Technol. 35, 648-653.

Lee, P.C., Lee, S.Y., Chang, H.N., 2008. Succinic acid production by Anaerobiospirillum succiniciproducens ATCC 29305 growing on galactose, galactose/glucose, and galactose/lactose. J. Microbiol. Biotechnol. 18(11), 1792-1796.

Lee, P.C., Lee, S.Y., Hong, S.H., Chang, H.N., Park, S.C., 2003. Biological conversion of wood hydrolysate to succinic acid by Anaerobiospirillum succiniciproducens. Biotechnol. Lett. 25(2), 111-114.

Lee, S.Y., Kim, J.M., Song, H., Lee, J.W., Kim, T.Y., Jang, Y.S., 2008. From genome sequence to integrated bioprocess for succinic acid production by Mannheimia succiniciproducens. Appl. Microbiol. Biotechnol. 79(1), 11-22.

Li, J., Zheng, X.Y., Fang, X.J., Liu, S.W., Chen, K.Q., Jiang, M., Wei, P., Ouyang, P.K., 2011. A complete industrial system for economical succinic acid production by Actinobacillus succinogenes. Bioresour. Technol. 102(10), 6147-6152.

Lin, H., Bennett, G.N., San, K.Y., 2005a. Metabolic engineering of aerobic succinate production systems in Escherichia coli to improve process productivity and achieve the maximum theoretical succinate yield. Metab. Eng. 7(2), 116-127.

Lin, H., Bennett, G.N., San, K.Y., 2005b. Fed-batch culture of a metabolically engineered 
Escherichia coli strain designed for high-level succinate production and yield under aerobic conditions. Biotechnol. Bioeng. 90(6), 775-779.

Lin, H., San, K.Y., Bennett, G.N., 2005c. Effect of Sorghum vulgare phosphoenolpyruvate carboxylase and Lactococcus lactis pyruvate carboxylase coexpression on succinate production in mutant strains of Escherichia coli. Appl. Microbiol. Biotechnol. 67(4), 515523.

Lin, H., Vadali, R.V., Bennett, G.N., San, K.Y., 2004. Increasing the acetyl-CoA pool in the presence of overexpressed phosphoenolpyruvate carboxylase or pyruvate carboxylase enhances succinate production in Escherichia coli. Biotechnol. Prog. 20(5), 1599-1604.

Liu, K., 1997. Soybeans: chemistry, technology, and utilization. Chapman and Hall, New York.

Luo, L., van der Voet, E., Huppes, G., 2010. Biorefining of lignocellulosic feedstock-Technical, economic and environmental considerations. Bioresour. Technol. 101(13), 5023-5032.

McKinlay, J.B., Vieille, C., Zeikus, J.G., 2007. Prospects for a bio-based succinate industry. Appl. Microbiol. Biotechnol. 76(4), 727-740.

Moniruzzaman, M., Lai, X., York, S.W., Ingram, L.O., 1997. Extracellular melibiose and fructose are intermediates in raffinose catabolism during fermentation to ethanol by engineered enteric bacteria. J. Bacteriol. 179(6), 1880-1886.

Sanchez, A.M., Bennett, G.N., San, K.Y., 2005. Novel pathway engineering design of the anaerobic central metabolic pathway in Escherichia coli to increase succinate yield and productivity. Metab. Eng. 7(3), 229-239.

Schmid, K., Ebner, R., Altenbuchner, J., Schmitt, R., Lengeler, J.W., 1988. Plasmid-mediated sucrose metabolism in Escherichia coli K12: mapping of the scr genes of pUR400. Mol. Microbiol. 2(1), 1-8. 
Schmid, K., Schmitt, R., 1976. Raffinose metabolism in Escherichia coli K12. Purification and properties of a new $\alpha$-galactosidase specified by a transmissible plasmid. Eur. J. Biochem. $67,95-104$.

Schmid, K., Schupfner, M., Schmitt, R., 1982. Plasmid-mediated uptake and metabolism of sucrose by Escherichia coli K-12. J. Bacteriol. 151(1), 68-76.

Shanmugam, K.T., Ingram, L.O., 2008. Engineering biocatalysts for production of commodity chemicals. J. Mol. Microbiol. Biotechnol. 15(1), 8-15.

Thakker, C., Martinez, I., San, K.Y., Bennett, G.N., 2012. Succinate production in Escherichia coli. Biotechnol. J. 7(2), 213-224.

Tolentino, G.J., Meng, S.Y., Bennett, G.N., San, K.Y., 1992. A pH-regulated promoter for the expression of recombinant proteins in Escherichia coli. Biotechnol. Lett. 14, 157-162.

Ulmke, C., Lengeler, J.W., Schmid, K., 1997. Identification of a new porin, RafY, encoded by raffinose plasmid pRSD2 of Escherichia coli. J. Bacteriol. 179, 5783-5788.

Wang, J., Zhu, J., Bennett, G.N., San, K.Y., 2011. Succinate production from sucrose by metabolic engineered Escherichia coli strains under aerobic conditions. Biotechnol. Prog. 27(5), 1242-1247.

Wang, Y.H., Duff, S.M., Lepiniec, L., Cretin, C., Sarath, G., Condon, S.A., Vidal, J., Gadal, P., Chollet, R., 1992. Site-directed mutagenesis of the phosphorylatable serine (Ser8) in C4 phosphoenolpyruvate carboxylase from Sorghum. The effect of negative charge at position 8 . J. Biol. Chem. 267(24), 16759-16762.

Werpy, T., Petersen, G., 2004. Top Value Added Chemicals from Biomass. USDOE, Washington DC. 
Xu, J., Guo, B.H., 2010. Poly(butylene succinate) and its copolymers: research, development and industrialization. Biotechnol. J. 5(11), 1149-1163.

Yoo, J., Alavi, S., Vadlani, P., Amanor-Boadu, V., 2011. Thermo-mechanical extrusion pretreatment for conversion of soybean hulls to fermentable sugars. Bioresour. Technol. 102(16), 7583-7590.

Yoo, J., Alavi, S., Vadlani, P., Behnke, K.C., 2012. Soybean hulls pretreated using thermomechanical extrusion-hydrolysis efficiency, fermentation inhibitors, and ethanol yield. Appl. Biochem. Biotechnol. 166(3), 576-589.

Zeikus, J.G., Jain, M.K., Elankovan, P., 1999. Biotechnology of succinic acid production and markets for derived industrial products. Appl. Environ. Microbiol. 51, 545-552. 


\section{Figure Captions}

Figure 1. Galactose metabolism by [A] HL2765(pKK313)(pRU600) and [B]

HL27659k(pKK313)(pRU600) at $24 \mathrm{~h}$

Figure 2. Sucrose metabolism by [A] HL2765(pKK313)(pRU600) and [B]

HL27659k(pKK313)(pRU600) at $24 \mathrm{~h}$

Figure 3. Raffinose metabolism by [A] HL2765(pKK313)(pRU600) and [B] HL27659k(pKK313)(pRU600) at $24 \mathrm{~h}$

Figure 4. Succinate production using $[\mathrm{A}]$ soybean meal extract and [B] soybean meal hydrolysate by HL2765(pKK313)(pRU600) and HL27659k(pKK313)(pRU600) at 24 h

Figure 5. Succinate production using soy solubles extract by HL2765(pKK313)(pRU600) and HL27659k(pKK313)(pRU600) at $24 \mathrm{~h}$

Figure 6. Succinate production using soy solubles hydrolysate by [A] HL2765(pKK313)(pRU600) and [B] HL27659k(pKK313)(pRU600) at $24 \mathrm{~h}$ and $48 \mathrm{~h}$ 
Table 1. Strains and plasmids used in this study

\begin{tabular}{|c|c|c|}
\hline $\begin{array}{l}\text { Strains / } \\
\text { Plasmids }\end{array}$ & Genotype / Phenotype & Source \\
\hline \multicolumn{3}{|l|}{ Strains } \\
\hline HL2765 & GJT001[ $[s d h A B, \Delta(a c k A-p t a), \Delta p o x B, \Delta i c l R]$ & Lin et al., 2005a \\
\hline HL27659k & $\begin{array}{l}\text { GJT001[ } \Delta s d h A B, \Delta(\text { ackA-pta }), \Delta p o x B, \Delta i c l R \\
\left.\Delta p t s G:: \mathrm{Km}^{\mathrm{R}}\right]\end{array}$ & Lin et al., 2005a \\
\hline \multicolumn{3}{|l|}{ Plasmids } \\
\hline & S8D mutant Sorghum vulgare pepc in pKK233-2, Ap ${ }^{\mathrm{R}} /$ & \\
\hline pKK313 & $\begin{array}{l}\text { Mutant рерс overexpression relieves malate feedback } \\
\text { inhibition and catalyzes the carboxylation of PEP to OAA }\end{array}$ & Wang et al., 1992 \\
\hline pHL413 & $\begin{array}{l}\text { Lactococcus lactis pyc in } \mathrm{pTrc} 99 \mathrm{~A}, \mathrm{Ap}^{\mathrm{R}} / p y c \\
\text { overexpression increases the flux from pyruvate to OAA }\end{array}$ & Lin et al., 2004 \\
\hline pUR400 & $\begin{array}{l}s c r K \text { (fructokinase), } s c r Y \text { (sucrose-specific porin), scr } A \\
\text { (enzyme } \mathrm{II}^{\mathrm{scr}} \text { of the phosphotransferase system), } \operatorname{scr} B(\beta \text {-D- } \\
\text { fructofuranoside fructohydrolase) and } s c r R \text { (regulator) } \\
\text { genes, } \mathrm{Tc}^{\mathrm{R}} / \text { allows the metabolism of sucrose by } \\
\text { converting sucrose 6-phosphate to } \beta \text {-D-fructose and } \alpha \text {-D- } \\
\text { glucose 6-phosphate }\end{array}$ & Schmid et al., 1988 \\
\hline pRU600 & $\begin{array}{l}\text { rafA ( } \alpha \text {-galactosidase), rafB (raffinose permease) and rafD } \\
\text { (sucrose hydrolase) in pACYC184, } \mathrm{Cm}^{\mathrm{R}} / \text { allows the } \\
\text { metabolism of raffinose and sucrose }\end{array}$ & $\begin{array}{l}\text { Schmid and Schmitt, } \\
\text { 1976; Aslanidis et } \\
\text { al., } 1989\end{array}$ \\
\hline
\end{tabular}



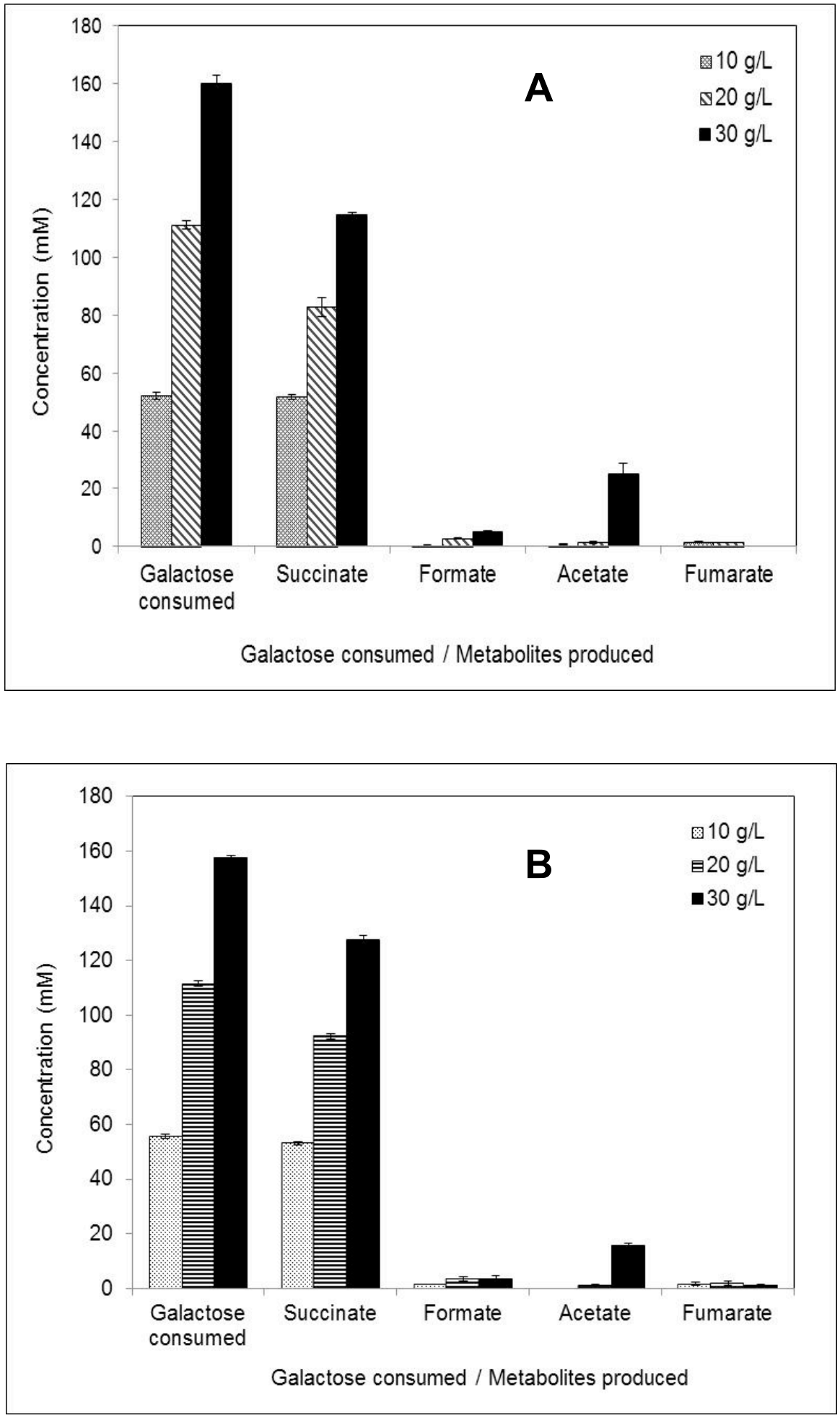

Figure 1. 

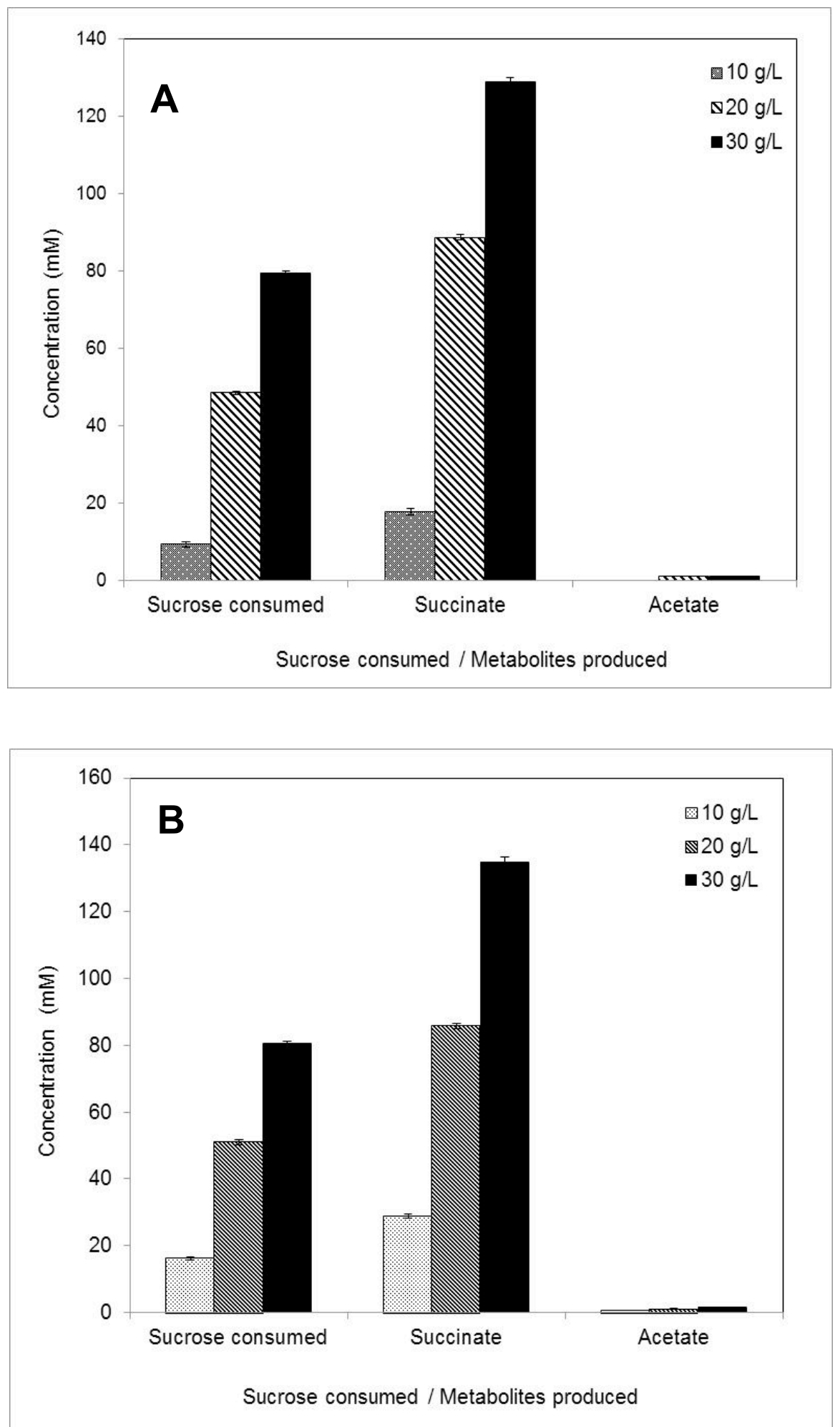

Figure 2. 

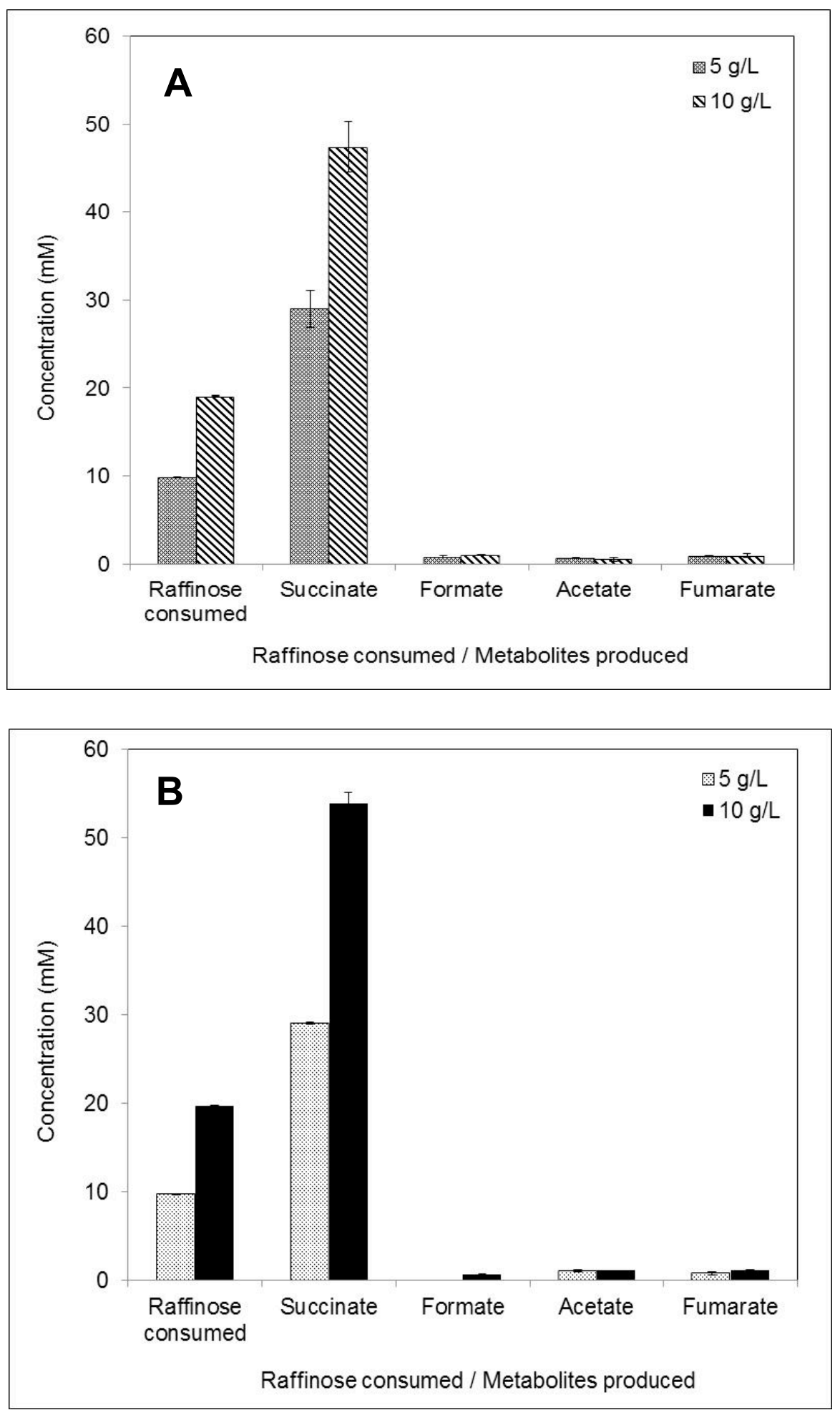

Figure 3. 

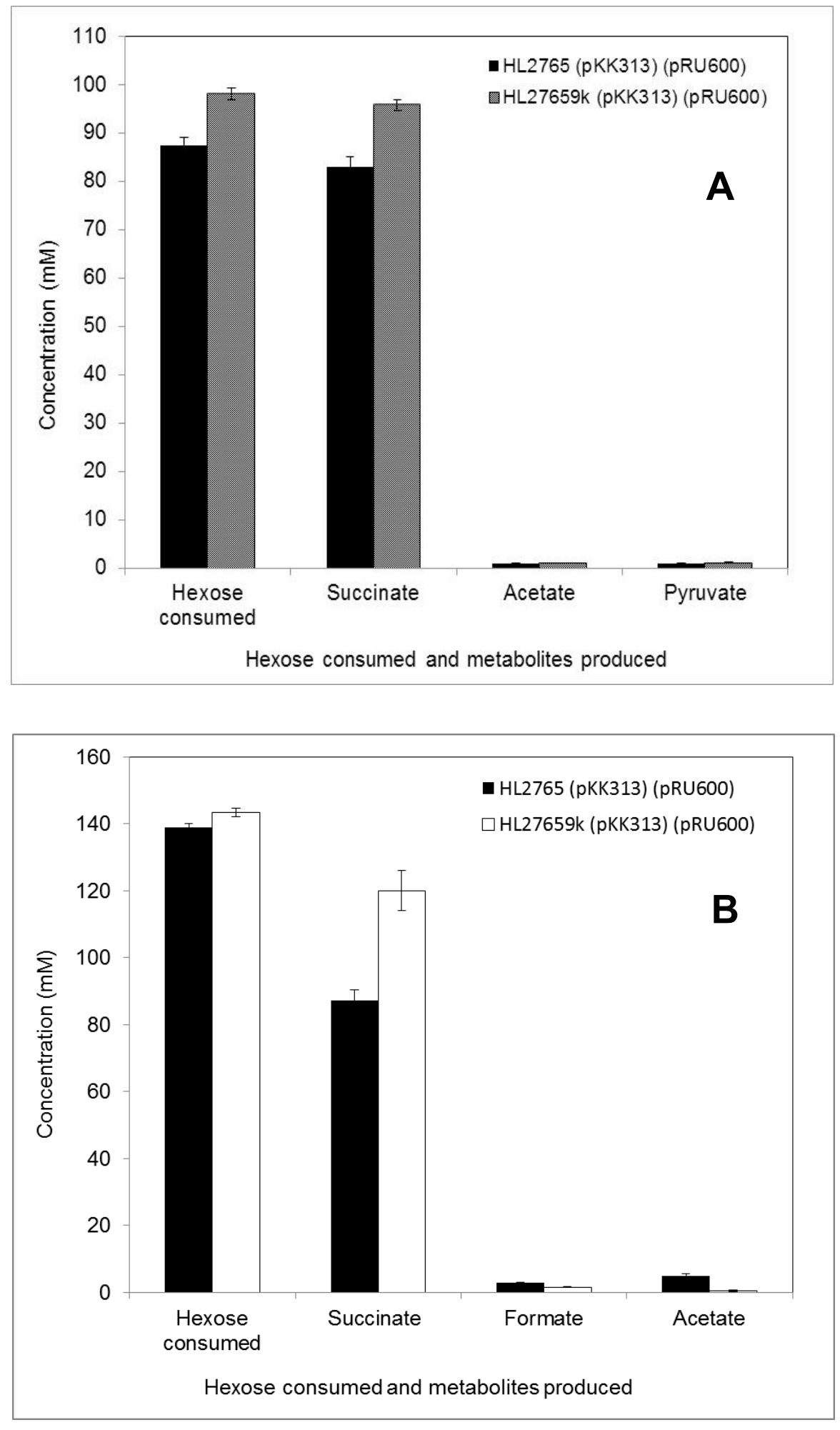

Figure 4. 


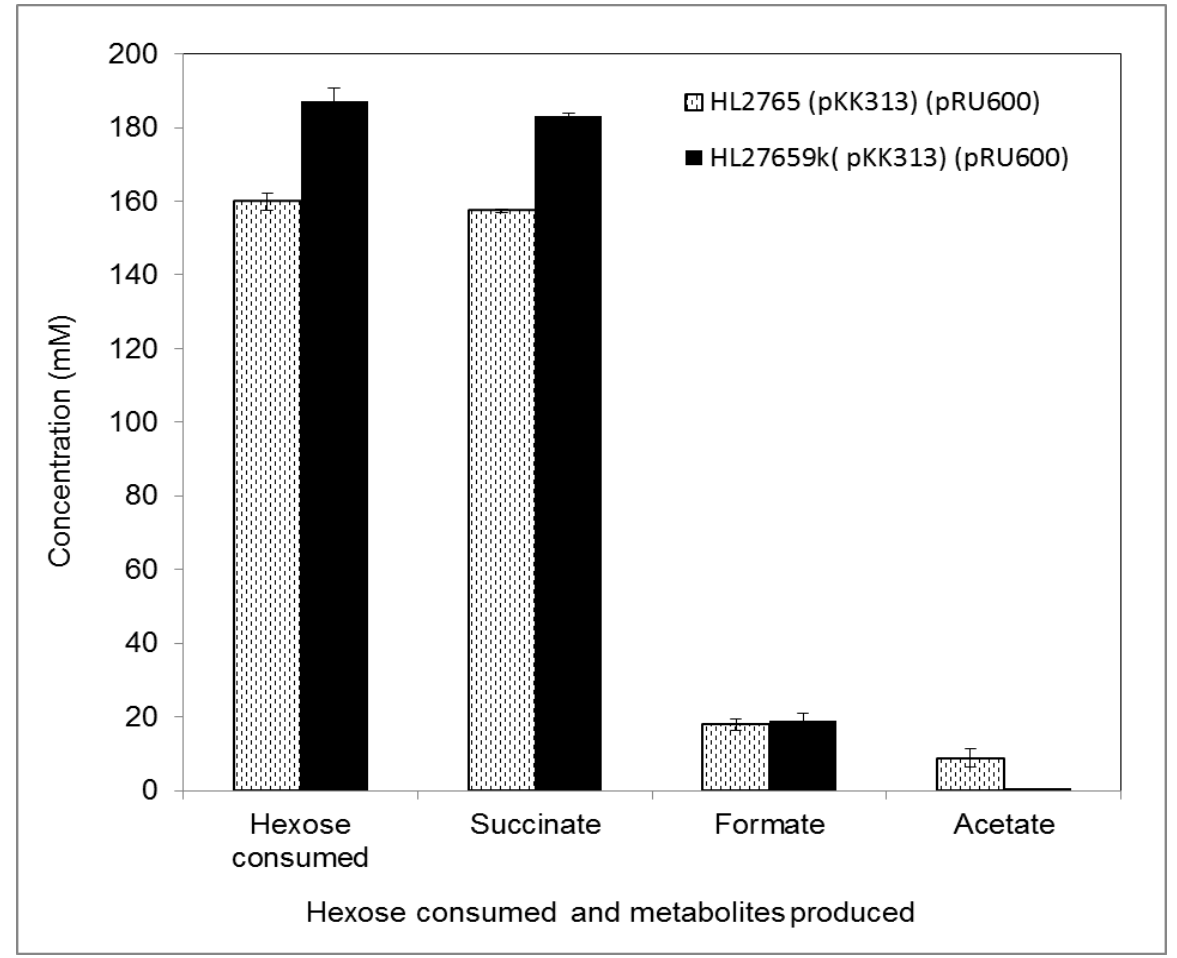

Figure 5 

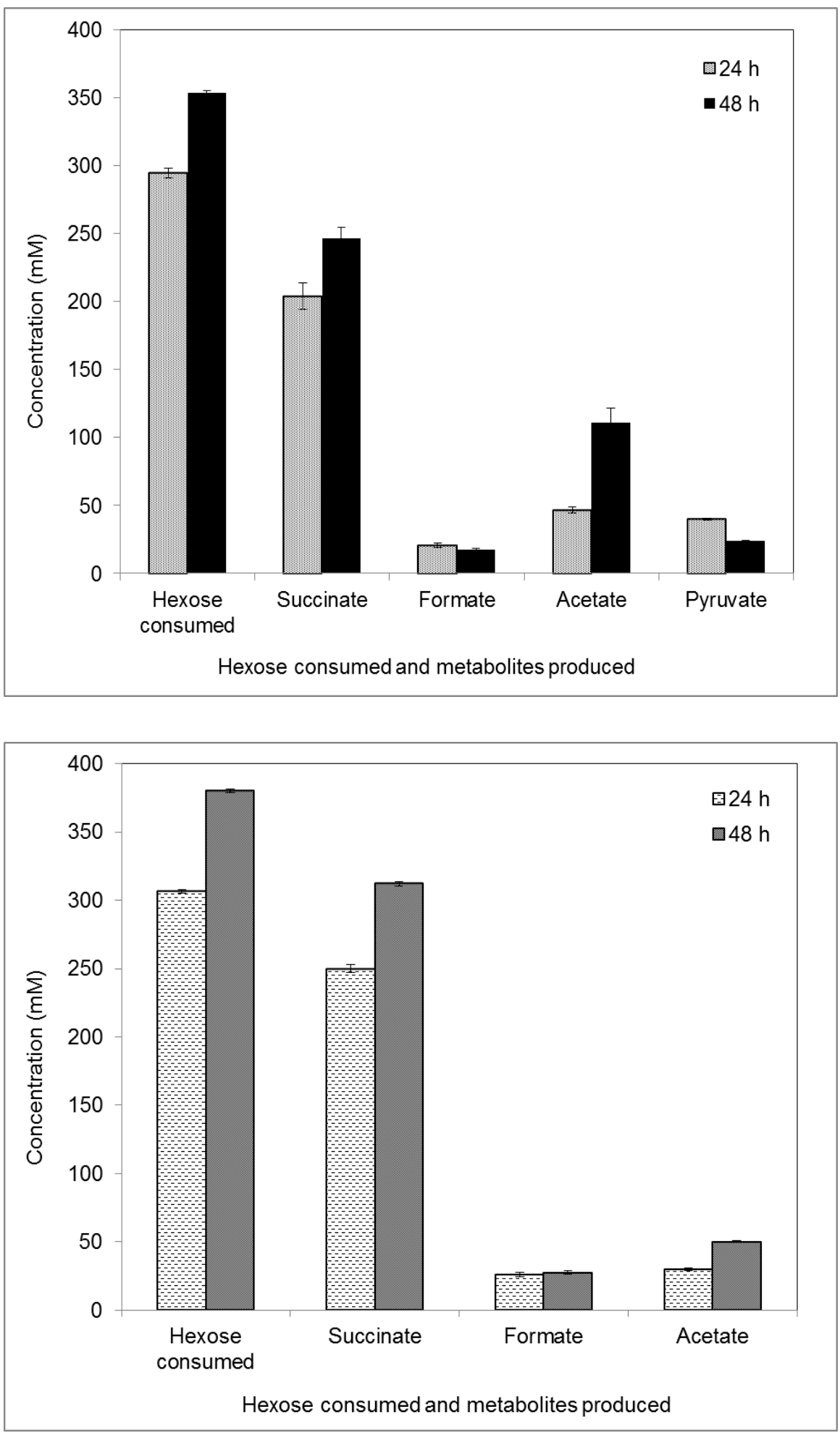

Figure 6. 